\title{
A Case Study of English Schwa Realization by Muna Language Speaker
}

\author{
Lia Maulia Indrayani ${ }^{1}$, Intan Siti Nugraha ${ }^{2}$
}

English Linguistics, Faculty of Cultural Sciences, Universitas Padjadjaran, Indonesia

\begin{abstract}
English schwa, a short vowel with mid-central quality, is absent in phonological system of Muna language. When a sound does not exist in one language, the speaker of the language tends to replace the sound with another similar sound, or eliminate the sound, or add a sound to make it possible to realize. Hence, in Muna language, there are only five vowels without varying long and short vowels, while there are 20 phonetic vowel symbols in Received Pronunciation and 16 in General American. Thus, this study attempts to investigate the realization of English schwa, a vowel which does not exist in Muna Language, by Muna Language speaker and the environment causing it. The speaker of Muna Language reading some words in sentences containing schwa is recorded. The data procured are analyzed by Praat, a freeware program for the analysis and reconstruction of acoustic speech signals. The findings are expected to be shown to some extend that firstly, some words containing English schwa are interpreted to certain vowel in Muna Language which is considered as a close counterpart of this short mid-central vowel (schwa) by the speaker. Secondly, the speaker tends to eliminate the sound to avoid mispronounce schwa that does not exist in Muna Language. All the findings could be taken into consideration when teaching English the speakers of language which does not have mid-central vowel or schwa in their language phonetic system. It highlights the importance of associating in teaching English phonemes, especially vowels, which might enhance the learners' realization of English schwa sound as it appears in actual words.
\end{abstract}

Keywords-English schwa, Muna Language, realization, vowels.

\section{INTRODUCTION}

Correct pronunciation is essential skill for English as Foreign Language (EFL) learners in communication (Taqi, et al., 2018). However correct pronunciation is difficult in which it mostly creates foreign accents and variation in pronunciation. Although the learners have acquired English as their new language, sometimes these pronunciation variations occur for some reasons. The phonological mismatches between the learners' first language and English as target language could be the main contribution to the difficulties. Moreover, the fact that English vowels have several ways of pronunciation could be a problematic to them whose L1's vowel sounds are not as various as English and very limited (Yavas, 2011).

As in most Indonesian EFL, their first language, their tribe's language, interferes more intensive than Indonesia language as their second language. One of the mismatches is the absence of short mid-central vowel (schwa), /ə/ in English as target language (L2) and most tribes' language in Indonesia (L1). It leads to some phonological process in adapting to acquiring English, such as feature-changing rules (assimilation and disassimilation), segment insertion and deletion (Fromkin et al, 2018).

Related to the realization of English schwa and phonological process involving this sound, there are several researchers conducting studies around it. The study about deletion of schwa was concerned by Torres (2019), Ryu and Hong (2013), Song (2006) and Szigetvári (2002). Those studies provide evidence that schwa deletion is strongly influenced by stress environment (pre-stress position vs.post-stress position), sonority distance between two consonants surrounding an unstressed vowel [ə], and lexical frequency of the word containing the schwa. Stress environment affects schwa deletion that schwa is more likely to delete in post-stress position than in pre-stress position.

Another study investigating schwa realization, especially by Indonesia speakers, was conducted by Aryani (2019). A study which investigated English schwa sound produced by students of language and Literature Faculty in UNSIQ was conducted by Aryani (2019). The students 
were given 15 words containing schwa to pronounce. Their pronunciations of those words were recorded. Each recorded word was listened again and identified in term of its schwa realization. The result shows that their pronunciation was interfered by students' mother tongue language. The existence of English schwa and their experience studying English do not mean that they alert with the correct pronunciation as they were instructed to pronounce given list words containing schwa sound. Schwa sound in all 15 words were replaced by the students into other sounds, such as low back vowel [a:], mid-back vowel [o:], and high-back vowel [u:].

Derived from the preceding studies, this study was aimed to investigate the realization of English schwa by Muna language speaker and the environment causing the realization.

\section{THEORITICAL FRAMEWORK}

\section{Schwa in English}

Schwa is a vowel like any other; a central open$\mathrm{mid} /$ close-mid unrounded vowel, slightly higher than [e], slightly more central than $/ \Lambda /$ : i.e. / / / (Silverman, 2011). In term of practice, schwa has been applied to a phonological value that is especially variable in its phonetic properties. In term of duration, Schwa is typically quite short, and this short duration may co-vary with its tendency to be coarticulated. Given its short duration and co-articulatory tendencies, schwa bears a phonetic similarity to the mere audible release of a consonantal constriction in the context of a following consonant (Silverman, 2011). Indeed, certain epenthetic schwas may have their origin in consonantal release. Although such schwas may play an important functional role by providing acoustic cues to the first consonant in such consonant-consonant sequences, these schwas may, in fact, be "invisible" to the prosodic structure of the language, contributing neither to the syllable structure nor to the metrical structure of the system (Hall 2006).

In acoustic terms, schwa's resonance structure may be modeled (as a first approximation) by a tube that has no significant constrictions anywhere along its length, such that its formants derive not from two tubes (and/or a Helmholtz resonator) as is the case for other vowels, but instead from one long tube. Given a tube that approximates the length of an adult male vocal tract, this idealized version of schwa possesses formants at $500 \mathrm{~Hz}, 1500 \mathrm{~Hz}$, $3500 \mathrm{~Hz}$, etc. (Johnson, 2003; Silverman, 2011). However, since schwa's articulatory properties are so variable typically, far more variable than other vowel qualities - its formant values vary in kind (Yavas, 2011).

\section{Muna Language}

Muna is an Austronesian Language belonging to Western Malay-Polynesian branch (Blust, 1980 in Van den Berg (1989). Muna language is originated and largely spoken in Muna Island, one of the biggest island at southeast coast of Sulawesi, Indonesia. Van den Berg (1989) distinguishes four dialects of Muna language. They are Standard Muna, Tiworo, Si ompu and Gumas. The speech variations are more than $80 \%$ of their basic vocabulary and phonological difference among the four dialects.

In phonological system of Muna Language, there are only five vowels. They are high front unrounded vowel /i/, high back rounded vowel /u/, low central unrounded vowel /a/, half-open-mid front unrounded vowel $/ \varepsilon /$ and half-open-mid back rounded vowel $/ \%$. In immediate environment, the half-close allophone /o/ occurs.

In corpus of over 1000 disyllabic roots (CV.CV sequence) the relative occurrence of $/ a /$ in final and penultimate syllable is the highest while the lowest occurrence is /i/. Muna language does not allow consonant cluster CC and word-final consonants in syllable structure. Meanwhile, sequence of three vowels (VVV) is very common. In sequence of two vowels, all vowels are found as either the first or the second. When two adjacent vowels are different, stress is regular and falls on the penult. However, when the two vowels are identical, the sequence is phonetically pronounced one long vocoid, as in word nee [ne:], laa [la:] and tuu [tu:]. Thus, the final unstressed vowel is absorbed into the preceding identical vowel.

As many languages in the world, Muna language has borrowed and still borrows vocabularies. Related to the process adaptation on borrowing words, in his research, Van den Berg (1989) classified four the phonological adaptations loan words in Muna language that tend to be done by Muna speakers. The phonological adaptations undergone are replacement of foreign sounds, avoidance of final consonants and breaking of clusters. In replacement of foreign sound, for instance, schwa sound /// tends to be replaced by low central unrounded vowel $/ \mathrm{a} /$. To avoid final consonant, Muna speakers delete final consonants or add a vowel in final position. The example of replacement schwa /ə/ and avoiding final consonant is found in word telat (Indonesian) which becomes talati (Muna)..

\section{METHODOLOGY}

In accordance with the purpose of the research related to analyzing the realization of English schwa [ə] produced by Muna Language speaker, the research 
employed descriptive qualitative research method since it places stress and describes in detail of what goes on in particular events or situations or activities rather than comparing the effects of a particular treatment (Burns, 1995; Creswell, 2012; Fraenkel, Wallen, \& Hyun, 2012).

\subsection{Participant}

The participant involved this study was a Muna Language speaker with no known speech or hearing defects who studies English Linguistic magister program. The participant was selected purposively to meet requirement of this study. Although he has been living in West Java for a year to study, he was an active Muna Language speaker in his daily lives in his neighborhood in Sulawesi. He is considered to have strong dialect and accent of Muna language in speaking other languages (such as Sundanese).

\section{2. Data Collection Technique}

The data of this study were collected through several stages. Firstly, the participant read 27 isolated words in a silent chamber. The word list read were recorded. All of the words selected were familiar words for the participant. The participant firstly previewed all the words listed and confirmed that all the words were familiar for him. Each word in the list contains schwa sound in different positions. There were three groups of words based on schwa positions read by participants. The first group was nine initial-position schwa words with /\#əC/ sequences. The second group was nine medial-position schwa words with $/ \mathrm{C} ə \mathrm{C} /$ sequence. The third group was nine final-position schwa words with /Co\#/ sequence. The list of the words is as follows:

Table-1. Phonological position of schwa

\begin{tabular}{lll}
$\begin{array}{c}\text { Word Initial: } \\
\# ə \mathbf{C}\end{array}$ & $\begin{array}{c}\text { Word Medial: } \\
\mathbf{C ə C}\end{array}$ & $\begin{array}{c}\text { Word Final: } \\
\text { Cə\# }\end{array}$ \\
\hline Alone & Present & Banana \\
\hline Against & System & Sofa \\
\hline Upon & Carrot & Area \\
\hline Obtain & Atlas & Idea \\
\hline
\end{tabular}

\begin{tabular}{lll}
\hline Abuse & Illness & Formula \\
\hline Achievement & Supply & Era \\
\hline Occasional & Circus & Villa \\
\hline Offensive & Curious & Cinema \\
\hline Afraid & Often & Propaganda \\
\hline
\end{tabular}

\section{3. Data Analysis}

After the data, the pronunciation of words containing schwa in different positions by Muna Language speaker, were obtained, acoustic-phonetic analysis was carried out by Praat software, 6.1.06 version. The schwa occurrence of each word was identified based on . Not only identified the schwa, each word recorded was transcribed to analyse the realization of schwa /ə/ sound.

Table-2. Phonological Transcription

\begin{tabular}{ll}
\hline Word & Pronunciation \\
\hline Alone & [ə'loøn] \\
\hline System & ['sis.təm] \\
\hline Sofa & ['soð.fə] \\
\hline
\end{tabular}

Speaker's pronunciation of all schwa position words were transcribed, analyzed, and compared to see the pattern that appeared. The pattern of schwa realization was analyzed in terms of phonological processes undergone and the circumstance such as stress environment (pre-stress syllable vs post-stress syllable) and consonants surrounding the schwa sound.

\section{FINDING AND DISCUSSION}

The findings obtained through transcription and acoustic-phonetic analysis are presented and discussed in this section. All the pronunciations of English words containing schwa produced by Muna language speaker were discussed in terms of their schwa realization and the environments. The productions are presented in the table below:

Table-3. Production of Potential-Schwa Words by Muna Language Speaker

\begin{tabular}{|c|c|c|c|c|c|}
\hline & & Words & $\begin{array}{c}* \text { GA } \\
\text { Pronunciation }\end{array}$ & $\begin{array}{l}\text { Muna Speaker } \\
\text { Production }\end{array}$ & Phonological Process \\
\hline \multirow{3}{*}{$\begin{array}{l}\text { Word } \\
\# ə C\end{array}$} & \multirow[t]{3}{*}{ Initial: } & Alone & [ə'loun] & [ə'loun] & - \\
\hline & & Against & [ə'genst] & [ə'geins] & - \\
\hline & & Upon & [ə'pa:n] & [Lpən] & Feature-changing Rules: \\
\hline
\end{tabular}




\begin{tabular}{|c|c|c|c|}
\hline & & & Replaced by $/ \underline{\Lambda} /$ \\
\hline & [əb'tein] & [obtern] & Feature-changing Rules: \\
\hline & & & Replaced by /o/ \\
\hline & [ə'bju:z] & [ebju:s] & Feature-changing Rules: \\
\hline & & & Replaced by / $\varepsilon$ / \\
\hline & Achievement [ə't $\left.\int \mathrm{i}: \mathrm{v} . \mathrm{m} ə \mathrm{nt}\right]$ & {$\left[\underline{\Lambda} \mathrm{t} \int \mathrm{i}: \mathrm{v} \cdot \mathrm{m} \partial \mathrm{nt}\right]$} & Feature-changing Rules: \\
\hline & & & Replaced by $/ \underline{\Lambda} /$ \\
\hline & [ə'keI.zən.əl] & 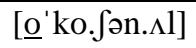 & Feature-changing Rules: \\
\hline & & & Replaced by /o/ \\
\hline & [ə'fen.siv] & [ofen.siv] & Feature-changing Rules: \\
\hline & & & Replaced by /o/ \\
\hline & [ə'freid] & {$[\underline{\Lambda}$ freid $]$} & Feature-changing Rules: \\
\hline & & & Replaced by $/ \underline{\Lambda} /$ \\
\hline Word Medial: & ['prez.ənt] & [pres.ən] & - \\
\hline $\mathrm{CaC}$ & ['sIs.təm] & [sIs.təm] & - \\
\hline & ['ker.ət] & [keru:t] & Feature-changing Rules: \\
\hline & & & Replaced by / $\underline{\mathrm{u}: /}$ \\
\hline & ['æt.ləs] & {$[\Lambda \mathrm{tl} \Lambda \mathrm{s}]$} & Feature-changing Rules: \\
\hline & & & Replaced by $/ \underline{\Lambda}$ \\
\hline & ['Il.nəs] & [Ilnəs] & - \\
\hline & [sə'plai] & [su:plai] & Feature-changing Rules: \\
\hline & & & Replaced by /u:/ \\
\hline & ['s3:.kəs] & [sIr.ku:s] & Feature-changing Rules: \\
\hline & & & Replaced by /u:/ \\
\hline & ['kjor.i.əs] & [k3riu:s] & Feature-changing Rules: \\
\hline & & & Replaced by / $\underline{\mathrm{u}: /}$ \\
\hline & ['a:f.ən] & [oftən] & - \\
\hline Word Final: Cə\# & [bə'næn.ə] & {$[\mathrm{b} ə \mathrm{n} \Lambda \mathrm{n} \Lambda]$} & Feature-changing Rules: \\
\hline & & & Replaced by / $\underline{\Lambda}$ \\
\hline & ['sou.fə] & {$\left[\mathrm{so}: \mathrm{f}_{\Lambda}\right]$} & Feature-changing Rules: \\
\hline & & & Replaced by $/ \underline{\Lambda}$ \\
\hline & ['er.i.ə] & ['er.i.ə] & - \\
\hline & [aI'di:.ə] & [aI'de $\Lambda]$ & Feature-changing Rules: \\
\hline & & & Replaced by $/ \underline{\Lambda}$ \\
\hline & ['fo:r.mjə.lə] & [formul $\Lambda]$ & Feature-changing Rules: \\
\hline & & & Replaced by / $\underline{\Lambda} /$ \\
\hline & ['Ir.ə] & {$[\operatorname{er} \Lambda]$} & Feature-changing Rules: \\
\hline & & & Replaced by / $\underline{\Lambda}$ \\
\hline & ['vil.ə] & {$[\operatorname{vil} \Lambda]$} & Feature-changing Rules: \\
\hline & & & Replaced by $/ \underline{\Lambda} /$ \\
\hline
\end{tabular}




\begin{tabular}{llll}
\hline Cinema & ['sin.ə.mə] & [sinem $\Lambda]$ & Feature-changing Rules: \\
\cline { 2 - 4 } & & Replaced by $/ \underline{\Lambda}$ \\
\hline Propaganda & [.pra:.pə'gæn.də] & [prop $\Lambda$ g $\Lambda$ nd $\Lambda]$ & Feature-changing Rules: \\
& & Replaced by $/ \underline{\Lambda} /$ \\
\hline
\end{tabular}

*Refer to phonetic transcription on Online Cambridge Dictionary

Based on Table-3, from the 27 words given to pronounce by the participant, only six words of potential schwa words are produced with schwa pertinently as in GA production. In group of initial-position schwa words, schwa sound as in GA pronunciation is identified in alone [ə'loun] and against [ə'geIns], while in final-position schwa words, it is only found in area ['er.i.ə]. More significant than in initial and final schwa position, in medial-position schwa words, there are four words identified to have schwa as in GA production.

The underlined phoneme in Muna speaker's production is the realization of schwa by the speaker. The schwa expected in the words is generally realized as other vowels. The phonological process undergone is featurechanging rules which is schwa sound is replaced by other sound (Fromkind, 2018). In summary, schwa sound is replaced by five vowels. They are low central vowel $/ \mathbf{N} /$, high back vowel /u:/, low-mid back vowel /s:/ and lowmid front vowel / $\varepsilon$ / .

The discussions of schwa realization of Muna language speaker then are elaborated in the following subsections based on the sound replacing schwa. The environments causing it, such as stress environment (prestress syllable vs post-stress syllable) and consonants surrounding the schwa sound are also investigated in detail.

\subsection{Schwa sound was replaced by low central vowel / $/$ /}

There are 12 words of schwa potential words in which the schwa is realized as / $\mathbf{N} /$ sound. The positions of schwa expected are various. The words are as follows:

Table-4.Realization of schwa sound by low central vowel $/ \mathrm{N}$

\begin{tabular}{|c|c|c|c|c|c|c|c|c|}
\hline \multicolumn{3}{|c|}{ Word Initial: \#əC } & \multicolumn{3}{|c|}{ Word Medial: CəC } & \multicolumn{3}{|c|}{ Word Final: Cə\# } \\
\hline Words & $\begin{array}{c}\text { GA } \\
\text { Pronunciation }\end{array}$ & $\begin{array}{c}\text { Muna } \\
\text { Speaker } \\
\text { Production }\end{array}$ & Words & $\begin{array}{c}\text { GA } \\
\text { Pronunciation }\end{array}$ & $\begin{array}{c}\text { Muna } \\
\text { Speaker } \\
\text { Production }\end{array}$ & Words & $\begin{array}{c}\text { GA } \\
\text { Pronunciation }\end{array}$ & $\begin{array}{c}\text { Muna } \\
\text { Speaker } \\
\text { Production }\end{array}$ \\
\hline Upon & [ә'pa:n] & [ıpən] & Atlas & ['æt.ləs] & {$[\Lambda \mathrm{tl} \Lambda \mathrm{s}]$} & Banana & [bə'næn.ə] & 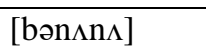 \\
\hline Achievement & [ə'tfi:v.mənt] & 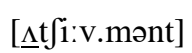 & & & & Sofa & ['sou.fə] & {$\left[\mathrm{so}: \mathrm{f}_{\Lambda}\right]$} \\
\hline Afraid & [ə'freId] & [ $\underline{\text { freid }]}$ & & & & Idea & [ar'di:.ə] & {$\left[a I^{\prime} \operatorname{de} \Lambda\right]$} \\
\hline & & & & & & Formula & ['fo:r.mjə.lə] & [formul $\Lambda]$ \\
\hline & & & & & & Era & ['Ir.ə] & {$[\operatorname{er} \Lambda]$} \\
\hline & & & & & & Villa & ['vil.ə] & {$[\operatorname{vil} \Lambda]$} \\
\hline & & & & & & Cinema & ['sin.ə.mə] & {$[\operatorname{sinem} \Lambda]$} \\
\hline & & & & & & Propaganda & [.pra:.pə'gæn.də] & {$[\operatorname{prop} \wedge \mathrm{g} \wedge \mathrm{nd} \Lambda]$} \\
\hline
\end{tabular}

According to Van den Berg (1989), Muna speakers tend to replace schwa with another vowel recognized in their language that is low central unrounded vowel /a/. Meanwhile, from Table-1, the speaker tended to use low central vowel $/ \mathbf{N}$. Table-1 shows that the schwa sound in almost all words with final-position schwa sound with Cə\# sequence is realized as low central vowel $/ \mathbf{N}$. Unfortunately, the schwa realization in these eight words might be influenced by orthography of the words such as banana, sofa, formula, era, villa, cinema and propaganda. The production of /ə/is [ $\mathbf{\Lambda}]$ because it is written by letter $a$ in bananaand in other words. In addition, the schwa in initial words with sequence \#əC replaced by $/ \mathbf{N} /$ was found in target words upon [ə'pa:n] as [ $\Lambda$ pən], achievement

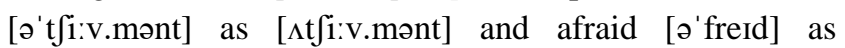
[ $\Lambda$ freId]. Interestingly, the participant pronounced upon [o'pa:n] as [ $\Lambda$ pən] in which schwa sound appears replacing low back vowel /a:/ and also changing the stress position. The Praat analysis of the word is presented below: 


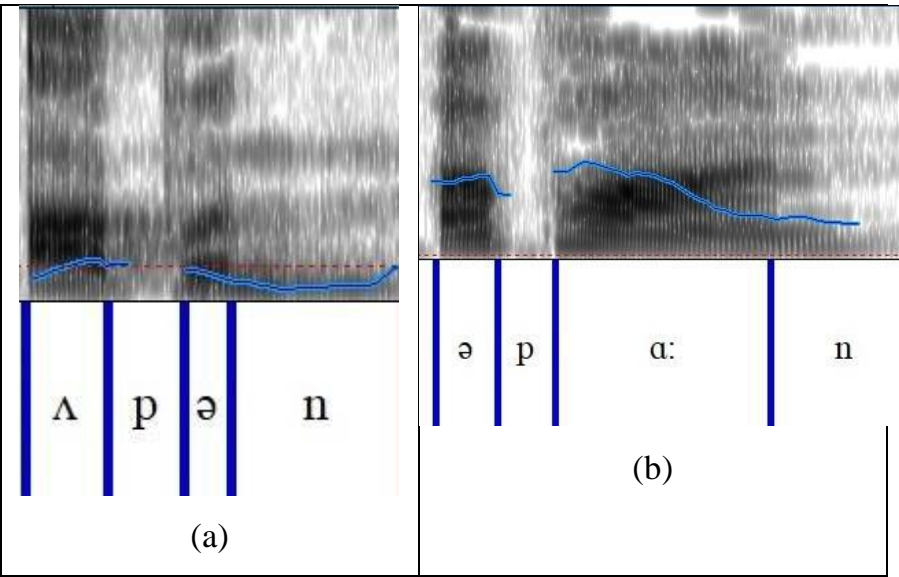

Fig-1: Spectrograms of the word "upon" realized by (a) Muna speaker and (b) GA pronunciation

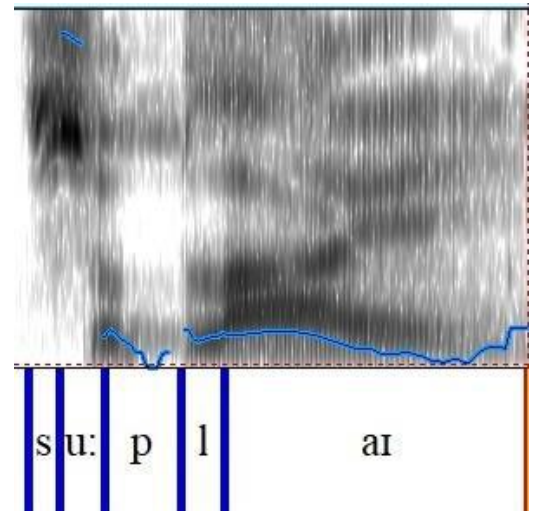

Fig.2: Spectrogram of the word "supply"

Figure-1 shows the difference position of schwa realized by Muna speaker. The participant changed the stress of word upon by replacing schwa in initial position by low central vowel $/ \mathbf{N}$.It is interesting because the schwa which appears in initial in GA pronunciation occurred in the second syllable replacing low-mid back vowel /o:/after voiceless bilabial stop $/ \mathrm{p} /$. Contrast with other words in which schwa is generally replaced by other vowel only or absent, in this case, the schwa is realized in different the position.

\subsection{Schwa sound was replaced by high back vowel/u:/}

The schwa sound which is realized as /u:/ sound appear in the group of medial-position schwa words with $/ \mathrm{C} \partial \mathrm{C} /$ sequence. No word in the initial and final position schwa words is replaced by high back vowel /u:/. There are four medial-position schwa words in which the schwa is replaced by this sound as in the table below:
Table-5. Realization of schwa by high back vowel /u:/

\begin{tabular}{lll}
\hline & \multicolumn{2}{c}{ Word Medial: CəC } \\
\hline Words & GA Pronunciation & $\begin{array}{c}\text { Muna Speaker } \\
\text { Production }\end{array}$ \\
\hline Carrot & ['ker.ət] & {$[$ keru:t] } \\
\hline Supply & [sə' plar] & [su:plar] \\
\hline Circus & ['sз':kəs] & [sIr.ku:s] \\
\hline Curious & ['kjor.i.əs] & [k3riu:s] \\
\hline
\end{tabular}

The occurrence of schwa in medial-position with sequence CəClike in carrot ['ker.ət], supply [sə'plar], circus ['s3'.kəs], and curious ['kjor.i.əs] is realized as high back vowel /u:/ by the participant. In pronunciation of carrot, the participant pronounced it as [keru:t] which only schwa sound is realized as other sound /u:/.

All of the three words except supply [sə'plai], the schwa position expected is in post-stress syllable. In supply, eventhough the schwa is in pre-stress syllable, it is realized as another vowel, /u:/ by the speaker. Schwa replacement changes the stress word as well. This leads to the new argument that the stress environment does not significantly influence the tendency of phonological process of feature-changing rule as in deletion (Ryu and Hong, 2013;Szigetvári, 2002). It is seen in Praat analysis /u:/ appears in replacing schwa as follows:

However in other three words, not only schwa sound is replaced by the speaker, but also other vowels are also realized into other vowels. For instance, r-colored vowel $/ 3 /$ in stressed syllables before a tautosyllabic as in circus ['s3'..kəs] is realized as $[\mathrm{I}]$.

\section{3. Schwa sound was replaced by low-mid back vowel} /):/

If the schwa replaced by high back vowel /u:/ only occurs in medial-position schwa words, there are only in initial-position words which the schwa is replaced by lowmid back vowel / $/ /$. The words are as follows:

Table-4. Realization of schwa sound by low-mid back vowel /o:/

\begin{tabular}{|c|c|c|}
\hline \multicolumn{3}{|c|}{ Word Inital: \#əC } \\
\hline Words & $\begin{array}{c}\text { GA } \\
\text { Pronunciation }\end{array}$ & $\begin{array}{c}\text { Muna Speaker } \\
\text { Production }\end{array}$ \\
\hline Obtain & [əb'teIn] & ['obteIn] \\
\hline Occasional & [ə'keı.zən.əl] & [o'ko.fən..$\Lambda 1]$ \\
\hline Offensive & [ə'fen.siv] & [ofen.siv] \\
\hline
\end{tabular}


The pattern of schwa realization by / $/$ / is clearly influence by orthography of the participant's language (L1).The target words containing schwa in initialunstressed syllable such as obtain [ob'tern] is pronounced as [obteIn] and it also changes the word stress. The word offensive [ə'fen.sIv] undergoes the same process which is pronounced [ofen.sIv]. In production of word occasional

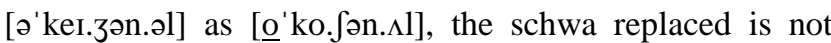
only in the initial-unstressed syllable, but also in the poststressed syllable. If the initial-position schwa is realized as low mid back vowel / o:/, the schwa in final syllable is realized as low central vowel / $\mathbf{N} /$.

The following is the analysis Praat of schwa realization in word offensive:

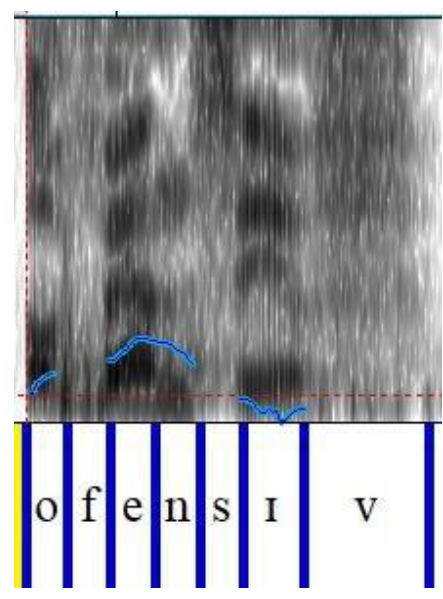

Fig.3: Spectrogram of the word "offensive"

Figure 3 shows low mid back vowel / o:/ is initiated the sounds replacing schwa expected as in GA production of word offensive[ofen.siv].

\section{4. Schwa sound was replaced by low-mid front vowel / $\varepsilon$ /}

The schwa which is realized by low-mid front vowel / $\varepsilon$ / by Muna language speaker is only found in word abuse.Abuse which in GA production is [ə'bju:z] is pronounced [Ebju:s]. The schwa replacement changes the stress word as well. The consonant following it is voiced bilabial stop.

Praat analysis of word abuse is presented below:

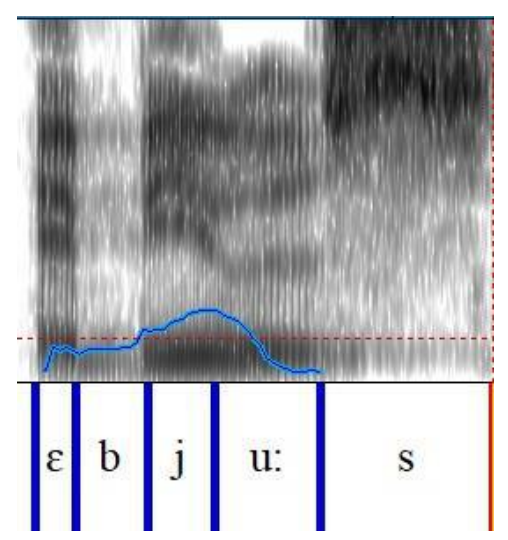

Fig.4: Spectrogram of the word "abuse"

\section{CONCLUSION}

Short mid-central vowel (schwa), /ə/, in English is absent in Muna language system. This leads to some phonological adaptation when Muna Language speaker pronounce English words containing schwa. After being tested to pronounce 27 words containing schwa in three different positions, the results of schwa realization are various. Generally, phonological process undergoes in realization schwa by the participant is feature-changing rule in which schwa is realized into other vowels, such as low central vowel $/ \Lambda /$, high back vowel /u:/, low-mid back vowel /s:/, low-mid front vowel $/ \varepsilon /$. The most frequent schwa replacement is by low central vowel $/ \Lambda /$.

The realization of those words leads to the changing word stress, since the schwa in unstressed syllable is realized into other vowels. In addition, the replacement of schwa occurs in both pre-stressed syllable and post-stressed syllable.

\section{REFERENCES}

[1] Ariyani, L. D. (2019). Pronunciation Error Analysis of English Schwa Sound Produced by the Students of UNSIQ. Metaphor, 1(1), 1-15.

[2] Braun, B., Lemhöfer, K., \& Mani, N. (2011). Perceiving unstressed vowels in foreign-accented English. The Journal of the Acoustical Society of America, 129(1), 376-387.

[3] Burns, R. B. (1995). Introduction to research methods. Melbourne: Longman Australia Pty Ltd.

[4] Creswell, J. W. (1994). Research design: qualitative and quantitative approach. California: Sage Publication Inc.

[5] Fraenkel, J. R., Wallen, N. E., \& Hyun, H. H. (2012). How to design and evaluate research in education (8th Edition ed.). New York: McGraw-Hill.

[6] Fromkin, V., Rodman, R., \&Hyams, N. (2018). An introduction to language. Cengage Learning.

[7] Hall, Nancy. (2006). Cross-linguistic patterns of vowel intrusion. Phonology (23) . 387-429 
[8] Johnson, Keith. (2003). Acoustic and auditory phonetics. 2nd edn. Malden, MA: Blackwell

[9] Silverman, D. (2011). Schwa. The Blackwell companion to phonology, 628-642.

[10] Song, Jieun. (2013). Variable schwa deletion in English: A corpus study. Studies in Phonetics, Phonology and Morphology 19(1): 33-52.

[11] Szigetvári, P. (2002). Syncope in English. The Even Yearbook, 5(2002), 139-49.

[12] Taqi, H. A., Algharabali, N. A., \& Akbar, R. S. (2018). The Realization of English Vowels by Kuwaiti Speakers. International Journal of English Linguistics, 8(4), $1-13$.

[13] Torres, E. (2019). Perceptions of Schwa Deletion by Speakers of American English(Doctoral dissertation, California State University, Northridge).

[14] Van den Berg, R. (1989). A grammar of the Muna language (Vol. 139). Dordrecht,, The Netherlands: Foris Publications.

[15] Yavas, M. S. (2011). Applied English Phonology. Blackwell Pub. 